Al-Manhaj: Journal of Indonesian Islamic Family Law, 3 (1), 2021: 70-80

ISSN: 2715-003; E-ISSN 2714-5514

DOI: http://dx.doi.org/10.19105/al-manhaj.v3i1.4787

\title{
The Dynamics Of Illegitimate Child Status In Sharia And National Law Of Indonesia: Is There A Harmonization?
}

\author{
Ahmad Rizza Habibi \\ (International Islamic University of Malaysia, email: rizza.habibi93@gmail.com)
}

\begin{abstract}
Abstrak:
Putusan Mahkamah Konstitusi Nomor 46/PUU-VIII/2010 adalah upaya reformasi hukum. karena menilai anak di luar nikah memiliki status yang sama dengan anak lainnya. meski terdapat ketidakharmonisan antara keputusan dan pengaturan bagi anak yang lahir di luar nikah akibat zina dalam hukum Islam. Artikel ini mengungkap peran Majelis Ulama Indonesia (MUI) terhadap proses harmonisasi hukum. Putusan ini menerapkan konsep Sadd al-Dzari'ah untuk menutupi kemungkinan zina sekecil apa pun sekaligus melindungi hakhak anak. (The decision of the Constitutional Court Number 46/PUU-VIII/2010 is an effort to reform the law because they judge that children out of wedlock have the same status as other children. However, disharmony exists between decisions and arrangements for children born out of wedlock due to adultery in Islamic law. This article reveals the Indonesian Ulama Council (MUI) legal harmonization process. However, this decision applies the concept of Sadd al-Dzari'ah to cover the slightest possibility of adultery while protecting children's rights.)
\end{abstract}

Kata Kunci:

Anak haram; Syariah; Hukum Nasional; Harmonisasi Hukum

\section{Introduction}

Children are the ones who need special care and protection because of their physical and mental vulnerability. Children born to parents whose relationship is not socially or legally recognized are one of the categories that are more vulnerable to discrimination. These

Available online at:

http://ejournal.iainmadura.ac.id/index.php/almanhaj/index

email koresproden: jayaloka85@gmail.com

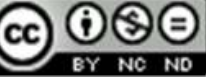


children are usually called illegitimate children. Kusum stated that despite international and national conventions prohibiting discrimination against any child and imposing responsibilities on parents, society and the state to protect it every manner, an illegitimate child is still exposed to enormous social, emotional and legal deprivation and discrimination. ${ }^{1}$

Illegitimate children have different status and rights with the legitimate child. In Indonesia, Illegitimate children only have the civil relationship with their mothers. Article 43 paragraphs (1) of Marriage Law states "a child born out of wedlock (Anak Luar Kawin) only has the civil relationship with his/her mother and his/her mother's family". This ruling has effect to the rights of illegitimate children. They have no rights to civil rights like legitimate child having to their biological father, such us: living (nafkah), inheritance (warits) and guardianship (wali).

To respond to these legal issues, legal reform has been made in accordance with the illegitimate child rights and status. The decision of Constitutional Court (MK) No. 46/PUU-VII/2010, regarding illegitimate children, aims to phase out discrimination among innocent children by rendering them the family relation not to their mother only but also the father. This change attempts to make effort that many children born illegally can have personal and equality right throughout children. ${ }^{2}$

However, the decision could invite controversy, especially on the Islamic legal discourse on the rights and status of illegitimate child. It would result in a change in the formulation of article 43 of Marriage Law and making all children born outside of legal marriages get the lineage (nasab) from their father. ${ }^{3}$ Consequently, both children born due to adultery (zina) or due to illegitimate marriages (sirri marriages) of their parents are equally entitled to the same rights and status according to national legal provisions. Obscurity over illegitimate child norms creates uncertainty about the law that must

\footnotetext{
${ }^{1}$ Kusum, Rights and Status of Illegitimate Children, Journal of the Indian Law Institute, Vol. 40, No. 1/4, Human Rights Special issue (1998), 296-307.

2 M. Nurul Irfan, Anak Luar Nikah Pasca Putusan Mahkamah Konstiusi Perspektif Konsep Nasab dalam Hukum Islam, Madania Scientific Journal, Vol. 16, No. 1, June (2012), 1.

${ }_{3}$ Muhammad Taufiki, Konsep Nasab, Istilhaq, dan Hak Perdata Anak Luar Nikah, AlAhkam, Vol. XII, No. 2, (2012), 59.
} 
be enforced in Indonesia. Whereas explicitly, in sharia it is said that the child resulting from adultery only has nasab to the mother. Therefore, this paper will try to analyze further to the debates on the dynamics of illegitimate child status in sharia and national law. Is there any way to harmonize the principles of human right vis a vis to the objective of Sharia (Maqashidus Syariah)?

\section{Result and Discussion}

The decision of the Constitutional Court (MK) No. 46/PUUVII/2010 can be categorized as a legal reform for status and rights of illegitimate child in Indonesian. The court reviews the arrangement of illegitimate child's civil relation with his parent in Marriage law. Therefore, the Constitutional Court rejects the norm of article 43 of Marriage Law which condition if it is interpreted as eliminating civil relations with the biological father. It is clearly stated in the decision that:

"The Article 43 of Marriage Law 'Children born outside of marriage only have a civil relationship with their mothers and their mothers' families' contrary to the 1945 Constitution of the Republic of Indonesia as long as it is interpreted as eliminating civil relations with men which can be proven based on science and technology and / or other evidence according to the law it turns out that it has a blood relationship as his father. So the article must be read, 'Children born outside of marriage having a civil relationship with his mother and his mother's family and with a man as his father which can be proven based on science and technology and / or other evidence according to the law to have blood relations, including civil relations with his father's family. 4

In principle, the decision is in line with the concept of the protection on the children's rights implied in article 27 paragraph (1), article 28B paragraph (2) and article 28I paragraph (2) of the 1945 Constitution. These articles state that all citizens together in their position in law and government, every child has the right to survival, to grow and develop and has the right to protection from violence and discrimination on any basis. In other words, with such arrangement, illegitimate child has an equal status and rights with the other child.

4 See the Constitutional Court's decision Number 46 / PUU-VIII / 2010. 
The decision implies that illegitimate child can have a civil relationship with both of their parent with such conditions. Therefore, this legal reform tries to destroy all the injustices experienced by illegitimate children so that they can receive all the same rights as those of legitimate children.

Nevertheless, there is legal obscurity in the interpretation made by the Constitutional Court on the legal meaning of the phrase "children born outside of marriage". The Court did not provide clear qualifications regarding the scope of the phrase "outside of marriage". Thus, children born because of sirri's marriage with those born because of adultery (zina) have the same status. Although the two categories are neither in accordance with the provisions concerning the validity of marriage in the Marriage Law. However, both have different legal implications, especially in religious law (in this case is Islamic law).

Basically, what is meant by children born due to sirri marriage are children born to parents whose relationship is not recognized by national law but is recognized by religious law. Meanwhile, children born because of adultery are children born to parents whose relationship is not recognized either by national law or by religious law.

Ordinary, in case of sirri marriage, it is a terminology to describe marriages that have fulfilled the requirements and get along according to fiqh, except that the marriage is not carried out in the presence of the Marriage Registrar (PPN) to be listed in accordance with the applicable regulations (Article 2 Marriage Law). ${ }^{5}$ If traced from a background event, the Constitutional Court Decision was the answer to the request for a material test submitted by Machica Mochtar married by Sirri with Moerdiono (former minister in the New Order era). The marriage produced a child named by M.Iqbal Ramadhan, but Moerdiono and his extended family did not recognize the marriage and the child he produced ${ }^{6}$

\footnotetext{
${ }^{5}$ Article 2 of Marriage Law (UUP) 1974: (1) Marriage is legal if carried out according to the laws of each religion and belief. (2) Each marriage is recorded according to the applicable laws and regulations. Prof. Dr. Drs. H. Abdul Manan, S.H., S. IP., M.Hum., Pembaruan Hukum Islam di Indonesia, (Depok: Kencana, 2017), 272.

6 See the Constitutional Court's decision Number 46 / PUU-VIII / 2010.
} 
However, in principle there is a procedure to legitimize illegitimate children caused by sirri marriage through a process of marriage certificate (itsbat nikah) in a Religious Court. Marriage certificate can be a media in arranging a child's birth certificate. Article 7 paragraph (1) of Compilation of Islamic Law (KHI) states: "Marriage can only be proven by a Marriage Certificate made by a Marriage Registrar." Marriage certificate is not only useful as proof of the existence of the marriage and guarantees for husband or wife in legal relationship according national law, but it also protect the rights of children born from this relationship such as the right to earn a living, inheritance, and marriage guardian. ${ }^{7}$

Therefore, without any application to the Constitutional Court, the status of illegitimate child due to sirri marriage, in fact, can be recognized with the procedure of itsbat nikah. It can be concluded that in this case, there are no legal impacts either from the side of national law or from the sharia side. In terms of national law, the status of illegitimate children can be protected through istbat nikah. And from the sharia side, their status is automatically received as legitimate child because the marriage of their parent is valid according to religious law (Islamic law). This can be seen from the pillars of marriage contained in Article $14 \mathrm{KHI}$ which requires: the existence of prospective husbands, prospective wives, guardians of marriage, two witnesses, and consent.

Conversely, conflict of laws can be occurred in case of children born outside of marriage due to adultery (zina). With the decision of the Constitutional Court which essentially stipulates that children born outside of marriage have a civil relationship with their biological mothers and fathers without the differentiation between illegitimate children due to sirri marriage or because adultery creates a conflict of norms with Islamic law. Because in Islamic law, maintaining the lineage (nasab) has a fundamental role due to it is one of the five goals of sharia (Maqashidus Sharia). ${ }^{8}$ Consequently, children born because

7 https://www.hukumonline.com/klinik/detail/1t55ed743e643cb/pengajuan-itsbatnikah-demi-kepentingan-anak-hasil-kawin-siri accessed on 10 November 2020.

${ }^{8}$ Maqashid al-Shariah is the main goal of the revelation of sharia. Scholars agree that Islamic sharia was revealed to safeguard five things, namely: protecting religion, soul, mind, lineage, and honor, and protecting property. Al-Syâthibî, al-Muwafaqat, (tp: Dar ibn Affan, 1997), II, 20. 
adultery cannot form a lineage relationship with their biological father for purpose to maintaining the lineage in Maqashidus Sharia perspective. In addition, on the one of sources of Sharia, namely Hadis, is clearly stated regarding the status of illegitimate child which reads:

$$
\text { الْولَد لِلِفَرَ ولِلَعَاهِر الحَجُر }
$$

This hadith explains that a child is associated with a bed (legal marriage), while a person who commits adultery, then he gets a loss. This means that a child born from a legal marriage immediately gets the right of lineage from his father without the need for recognition or other ways of determining the lineage. It is because, marriage means that the wife can only have intercourse with her husband, so that when the wife becomes pregnant, it can be ascertained that the fetus she is carrying is the result of a relationship with her husband.

In relation to that, Ibn Hazm has an argument that child born due to adultery only has an inherited relationship with his biological mother. The child also only has rights such as good treatment, provision of a living, mahram relations and various provisions of other legal relations with their biological mother. ${ }^{10}$ The scholars of imam madzhab also agree that a child born due to adultery has the position of another person with his biological father, so that he cannot inherit each other and cannot be connected with his lineage with his biological father. In addition, the father is also not obliged to provide a living, is not allowed to sit together and cannot be the guardian of marriage for his adulterous daughter. ${ }^{11}$

Eventually, it can be said that there is a disharmony between the Constitutional Court decision and the arrangement of children born because zina in Islamic law. In this level, harmonization between sharia and civil law is needed to face the problem. As explained

\footnotetext{
9 Al-Bukhârî, Shahîh al-Bukhârî, Hadis no. 2053; Muslim, Shahîh Muslim, Hadis no.

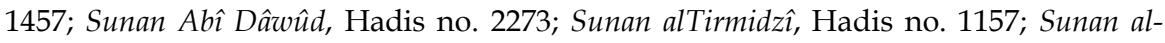
Nasâ' $\hat{\imath}$, Hadis no. 3482; Sunan Ibn Mâjah, Hadis no. 2006; al-Muwaththa` Mâlik, Hadis no. 20; Musnad al-Syâfi'î, Hadis no. 1201.

10 Nurul Irfan, Nasab Dan Status Anak Dalam Hukum Islam (Nasab and Status of Child in Islamic Law), Jakarta: Amzah, 2013, 118

11 Abdu ar-Rahman al-Jaziry,al-Figh 'Ala al-Madzahib al-Arba'ah, jilid 5, (Beirut : Dar alKutub al-Ilmiyyah, 2003), 121.
} 
before, Hashim Kamali attempt to suggest a tentative methodology for harmonization utilize the ushul formulas such as selection (takhayyur), piecing together (talfliq), Sharia-oriented policy (siyasah shar'iyyah), goals and objectives of Sharia (maqashid al-shar'iyyah), as well as fatwa, istihsan, and ijtihad.

If we look in more detail into the development of legal arrangement with regard to illegitimate children in Indonesian legal perspective, the legal harmonization approach between national law and sharia has been carried out by Indonesia Ulema Council (MUI) by issuing fatwa number 11 of 2012 concerning the position of children caused by zina and the treatment of them.

The MUI scholars have used the concept of ushuliyyah in the Fatwa as has been conceptualized by Kamali, where the process of takhayyur and talfiq is applied to ijtihad and harmonization of law. In a fatwa formula issued by the MUI, the scholars give consideration to legal issues and then provide the basis for legal sources of the provisions in the Qur'an, hadith, ijma 'ulama, atsar sahabat and the rules of ushuliyyah. Next, the scholars take several references to the results of the jurists of fiqh madhzhab and several books of fiqh. At the end, there was a decision of the MUI which tried to harmonize the provisions that had been extracted into fiqh with the legal system in Indonesia (Sharia-oriented policy).

As a basis for its stipulation, the MUI in its fatwa refers to the opinion of Jumhur of the Hanafiyyah, Malikiyyah, Syafiiyyah, and Hanabillah Fiqh' Madzhab which state that the principle of nasab determination is because a legitimate marriage relationship. Aside from being a legitimate marriage, there is no legal consequence of the relationship, and thus the child of zina is given to his mother, not to the men who insult.

The MUI also gave views from some of the previous ulama in several books, one of which was Wahbah al-Zuhaili's opinion with the title "Ahkam al-Aulad al-Natijin 'an al-Zina". It is explained that, if a man committed adultery with a woman who had a husband and then gave birth to a child, there would be ulema, as stated by Imam Ibn Abdil Barr in "al-Tamhid" (8 / 183) which confirms that the child is not condemned to the man who raped her, but to the husband of his mother, with condition that he does not deny the child through li'an. Meanwhile, if he commits adultery with a woman who is not bound 
by marriage and giving birth to a child, then according to the number of scholars of the eighth school of Islam, the child is only sent (nasab) to his mother even though there is recognition from the man who raped her. This is because the nasab connection of children to adulterous men will encourage the opening of the door of adultery, even though we are told to close the door which leads to prohibition (sadd al-dzari'ah) in order to maintain the sanctity of the blood from munkarat behavior. ${ }^{12}$

Furthermore, in the maqasid al-sharia, there is al-dharuriyat alkhams or the five souls of sharia as the fundamental purpose of the enactment of Islamic law by Allah, where one of the objectives is to preserve the lineage or the legal descendants. In order to safeguard this lineage, the religion of Islam prohibits all forms of adultery and prostitution and strongly advocates marriage to carry out the offspring of mankind, and a child can have a legal relationship with his father and biological mother. ${ }^{13}$ In consequence, connecting the nasab of children out of wedlock as a result of zina to the mother is an attempt to apply the qaidah of Sadd al-Dzari'ah to cover the slightest opportunity for zina and its legal consequences.

Therefore, the MUI fatwa decided that the children out of wedlock because zina had only a relationship of nasab, inheritance and nafaqah with their mother and mothers' family. However, to protect children's rights, the fatwa provides advice to the authoritative Government to sentence ta'zir to a man who commits zina by fulfilling the living needs of a child (as a substitute for income/naqfaqah) and providing assets after he dies through a wasiat wajibah (as a substitute for inheritance). The government is also advised to provide facilities for birth certificate services to these children, but do not connect nasab to men who have caused their birth. ${ }^{14}$

In the end, it can be said that the MUI Fatwa Number 11 of 2012 concerning the position of Children outside Marriage due to Adultery does not only take into account the objectives of sharia (Maqashidus Syariah) but also pay attention to aspects of human rights. The

12 Fatwa of Indonesian Council of Ulama (MUI) Number 11 of 2012, 9.

13 M. Nurul Irfan, 13.

${ }^{14}$ Fatwa of Indonesian Council of Ulama (MUI) Number 11 of 2012, 10. 
Constitutional Court's decision Number 46 / PUU-VIII/2010 which is still considered general and gives rise to several interpretations, it is necessary to pay attention to the results of the provisions of the MUI Fatwa as a reference in applying the law in the case of illegitimate child. At the practical level, fatwas contribute to the Religious Courts as guidelines for judges.

Although fatwas are not legally binding in the sense that there is no obligation for the judge to use the fatwa referred to in the litigation process. However, the MUI fatwa is seen as considered a legal opinion or can serve as a guideline for Religious Court judges in preparing the basis for consideration. ${ }^{15}$

\section{Conclusions}

The decision of Constitutional Court (MK) No. 46/PUUVII/2010 attempts to make effort that many children born illegally can have personal and equality right throughout children. However, this ruling caused some debates because the Court did not provide clear qualifications for the legal meaning of the phrase "born outside of marriage". Consequently, children born because of sirri marriage and those born because of adultery (zina) have the same right to have relationship with biological mother and father. Whereas, the two terms have different legal implications especially in Islamic law.

In the article, it is found that this ruling could be applied to children born because of sirri marriage, because this marriage is considered valid according to religious law (Islam). So, although the marriage is not recognized by national law, with the Constitutional Court decision, the children can have the relationship with the biological father without any conflict of law with Islamic law.

Conflict of laws can be occurred in case of children born outside of marriage due to adultery (zina). Because the decision is contrary to maqashid syariyyah especially in term of the rights and nasab of children born outside of marriage due to zina. In addition, it will also open the way for people to commit adultery. The legal

15 Zafrullah Salim, "Kedudukan Fatwa dalam Negara Hukum Republik Indonesia", in Puslitbang lektur dan Khazanah Keagamaan, 2012, Fatwa Majelis Ulama Indonesia (MUI) dalam Perspektif Hukum dan Perundang Undangan, Badan Litbang dan Diklat Kementerian Agama, Jakarta, 587. 
harmonization approach has been carried out by Indonesia Ulema Council (MUI) by issuing fatwa number 11 of 2012 concerning the position of children caused by zina and the treatment of them. MUI decided that the children had only a relationship of nasab, inheritance and nafaqah with their mother and mothers' family. However, to protect children's rights, the fatwa provides advice to the authoritative Government to sentence ta'zir to a man who commits zina by fulfilling the living (as a substitute for income/naqfaqah) and providing assets after he dies through a wasiat wajibah (as a substitute for inheritance). The Fatwas of MUI is tried to harmonize the provisions that had been extracted into figh with the legal system in Indonesia (Sharia-oriented policy).

\section{Daftar Pustaka}

Al-Jaziry, Abdurrahman, Al-Figh 'Ala al-Madzahib al-Arba'ah. Beirut: Dar al-Kutub al-Ilmiyyah, 2003.

Al-Syâthibî, al-Muwâfaqât, t.tp: Dâr ibn Affân, 1997

Gawas, Vijay M, Doctrinal legal research method a guiding principle in reforming the law and legal system towards the research development. International Journal of Law, Vol 3, 2017.

Irfan, M. Nurul, "Anak Luar Nikah Pasca Putusan Mahkamah Konstiusi Perspektif Konsep Nasab dalam Hukum Islam", Vol. 16, No. 1, Juni, 2012.

Irfan, M. Nurul, Nasab Dan Status Anak Dalam Hukum Islam, Jakarta: Amzah, 2013.

Kamali, Hashim, "Sharī'ah and Civil Law: Towards a Methodology of Harmonization", Islamic Law and Society Journal, Vol. 14, No. 3, 2007.

Kusum, "Rights and Status of Illegitimate Children", Journal of the Indian Law Institute, Vol. 40. No. 1/4, 1998.

Manan, H. Abdul, Pembaruan Hukum Islam di Indonesia, Depok: Kencana, 2017.

Salim, Zafrullah, Kedudukan Fatwa dalam Negara Hukum Republik Indonesia, Puslitbang lektur dan Khazanah Keagamaan, 2012, Fatwa Majelis Ulama Indonesia (MUI) dalam Perspektif Hukum dan Perundang-undangan, Badan Litbang dan Diklat Kementerian Agama, Jakarta. 
Taufiki, Muhammad, Konsep Nasab, Istilhaq, dan Hak Perdata Anak Luar Nikah. Al-Ahkam, Vol. XII, No. 2, 2012.

Decision of Constitutional Court Number 46 / PUU-VIII / 2010.

Fatwa of Indonesian Council of Ulama (MUI) Number 11 of 2012.

https://www.hukumonline.com/klinik/detail/lt55ed743e643cb/pen gajuan-itsbat-nikah-demi-kepentingan-anak-hasil-kawin-siri, accessed on 10 November 2020. 